\title{
Syzygium polyanthum (Wight.) Walp Ethanol Extract Decreased Malondialdehyde Level in Type 2 Diabetic Patients
}

\author{
Tri Widyawati ${ }^{1 *}$, M. Aron Pase ${ }^{2}$, Milahayati Daulay ${ }^{3}$, Imam Bagus Sumantri ${ }^{4}$
}

\section{Tri Widyawati ${ }^{1} *$, M. Aron Pase ${ }^{2}$, Milahayati Daulay ${ }^{3}$, Imam Bagus Sumantri ${ }^{4}$}

'Department of Pharmacology and Therapeutic, Faculty of Medicine, Universitas Sumatera Utara, Medan, 20155, INDONESIA. ${ }^{2}$ Department of Internal Medicine, Faculty of Medicine, Universitas Sumatera Utara, Medan, 20155, INDONESIA.

${ }^{3}$ Department of Physiology, Faculty of Medicine, Universitas Sumatera Utara Medan, 20155, INDONESIA.

${ }^{4}$ Department of Pharmacy Biology, Faculty of Pharmacy, Universitas Sumatera Utara, Medan, 20222, INDONESIA.

\section{Correspondence}

Tri Widyawati

Department of Pharmacology and Therapeutic, Faculty of Medicine, Universitas Sumatera Utara, Dr. T. Mansur street No. 5, Medan, 20155, Indonesia Phone no: 061-8126582932

E-mail: tw_rozan@yahoo.com/tri.widyawati@ usu.ac.id

History

- Submission Date: 21-09-2021;

- Review completed: 10-10-2021.

- Accepted Date: 21-10-2021.

DOI : 10.5530/pj.2021.13.198

Article Available online http://www.phcogj.com/v13/i6

Copyright

(C) 2021 Phcogj.Com. This is an openaccess article distributed under the terms of the Creative Commons Attribution 4.0 International license.

\begin{abstract}
Background: Beside conventional oral antidiabetic, many diabetic patients used plant as an alternative medicine. One of the plants is Syzygium polyanthum Wight. Walp. Previous study showed that ethanolic extract of Syzygium polyanthum (Wight.) Walp leaves (EESP) is safe to be consumed by healthy volunteer. Aim: The present study was conducted to investigate the effect of EESP on malondialdehyde (MDA) leve in type 2 diabetes mellitus volunteers. Materials and Methods: EESP was obtained by maceration then formulated in capsules (weight of $350 \mathrm{mg}$ ). A total of 12 volunteers were randomly given EESP or Placebo/ $\mathrm{PI}$ (amylum) once daily for 14 days in conjunction with metformin $500 \mathrm{mg}$ twice daily. Hemoglobin (Hb), liver and kidney function and MDA were measured at the beginning and at the end of the study. Results After 14 days administration of EESP, Hb 12.52 \pm 1.23 (g/dL), SGOT 24.16 \pm 13.57 (U/L), SGPT $27.50 \pm 20.52$ $(\mathrm{U} / \mathrm{L})$, ureum $23.12 \pm 13.27(\mathrm{mg} / \mathrm{dL})$, creatinine $0.71 \pm 0.23(\mathrm{mg} / \mathrm{dL})$ while MDA $1041.63 \pm 615.66 \mathrm{ng} / \mathrm{mL}$ in EESP treated group. The reduction of MDA level in EESP-treated group (24\%) were higher than Pl-treated group (16\%). Conclusion: S. polyanthum leaf extract is potential as antioxidant in type 2 diabetes mellitus patients.

Keywords: Diabetes mellitus; Extract; Malondialdehyde; S. polyanthum
\end{abstract}

\section{INTRODUCTION}

Diabetes mellitus (DM), commonly known as diabetes, is a group of metabolic disorders characterized by the presence of hyperglycemia in the absence of treatment. The heterogeneous aetiopathology includes defects in insulin secretion, insulin action, or both. The long-term specific complications of diabetes include retinopathy, nephropathy, and neuropathy. ${ }^{1}$ As a chronic illness, this disease requiring continuous medical care with multifactorial risk-reduction strategies beyond glycemic control. ${ }^{2}$

In the world and in all regions, DM is found in every population, including rural parts of low- and middle-income countries. WHO estimates there were 422 million adults with diabetes worldwide in 2014. The age-adjusted prevalence in adults rose from $4.7 \%$ in 1980 to $8.5 \%$ in 2014 , with the greatest increase in low- and middle-income countries. ${ }^{1}$

There are considerable evidences that many of the biochemical pathways which generates reactive oxygen species (ROS) are activated by hyperglycemia which ultimately leads to oxidative stress. ${ }^{3,4}$ Increased rate of free radical production and/or impaired antioxidant mechanisms are responsible for the high of oxidative stress level. These condition are related to insulin resistance, impaired glucose tolerance and $\beta$-cell dysfunction. Malondialdehyde (MDA), an organic compound, which is produced by ROS of lipid peroxidation process can be used as a marker in the development and progression of diabetes and its complication. ${ }^{5}$ Therefore, the evaluation of MDA level can be used as a marker of oxidative stress which can predict the potency of antioxidant activity of an agent.

Medication using medicinal plants is believed has lower side effects and relatively low cost than synthetic drugs..$^{6-8}$ In treatment perspective, the treatment of this disease need long term of antidiabetic agent consumption. Due to these issue, many diabetic patients used plants as the alternative medicine beside the conventional oral antidiabetic agent, one of which is Syzygium polyanthum Wight. Walp. ${ }^{9}$ Its leaves has been reported to have biological activity such as antihyperlipidemic ${ }^{10,11}$, larvacid ${ }^{12}$, antidiabetic ${ }^{13-15}$, and antioxidant as well. ${ }^{16-18}$ These beneficial activites related to the active constituents of this plant, i.e essential oil, eugenol, methyl chavicol, flavonoids, alkaloids, tannins, steroids, triterpenoids and squalene. ${ }^{9,19-20}$

The present study was conducted to evaluate the effect of extract ethanol of Syzygium polyanthum Wight. Walp leaf on malondialdehyde level in type 2 diabetic patients.

\section{MATERIALS AND METHODS}

\section{Time and place}

The study was conducted from April to November 2019 at Pharmacy Faculty and Medical Faculty of Universitas Sumatera Utara, Primary Health Care Glugur Darat, Medan and Integrated Laboratory of Medical Faculty, Universitas Sumatera Utara. A protocol has been approved by Health Research of Ethical Committee (No.616/TGL/KEPKFKUSURSUP HAM/2019).

\section{Extract preparation}

The leaves of Syzygium polyanthum Wight. Walp were collected from Medan region, North Sumatera, Indonesia. The selected leaves were washed in tap running water, then were dried in drying cabinet. The dried leaves, then were mashed into powder form. The powder was macerated using $70 \%$ ethanol, to obtain the Ethanol Extract of $S$. polyanthum Leaves 
(EESP). Plant identification was confirmed by Herbarium Medanense (MEDA), Universitas Sumatera Utara, Medan, Indonesia.

\section{Determination of total phenolics}

Total phenolic content was determined with the Folin-Ciocalteu reagent. ${ }^{21}$ A calibration curve was obtained by using gallic acid as standard. An amount of $5 \mathrm{mg}$ gallic acid was dissolved in $100 \mathrm{ml}$ methanol as a standard solution. Then it was diluted to $62.5 ; 125 ; 500$ $\mu \mathrm{g} / \mathrm{ml} .10 \mathrm{mg}$ sample was diluted in $10 \mathrm{ml}$ methanol on the test tube. As mush as $0.1 \mathrm{ml}$ of both standards and samples solutions were taken and mixed with $0.5 \mathrm{ml}$ of Folin-Ciocalteau and $7.9 \mathrm{ml}$ of distilled water, vortexed for \pm 1 minute, and added $1.5 \mathrm{~mL}$ of Na2 CO3 $20 \%$, then incubated for 90 minutes. The absorbance of all standards and samples were measured at $400 \mathrm{~nm}$ to $800 \mathrm{~nm}$ using Shimadzu $1800 \mathrm{UV}$-Vis spectrophotometer and the results expressed as milligrams of gallic acid equivalents (GAE) per g of extract.

\section{Determination of total flavonoids}

Total flavonoid was analyzed using aluminium chloride colourimetric method. ${ }^{21}$ Quercetin was used to make the calibration curve. $10 \mathrm{mg}$ of quercetin was dissolved in $100 \mathrm{ml}$ ethanol $96 \%$ and diluted to 6, 10, $14.5,19$, and $23.5 \mu \mathrm{g} / \mathrm{mL} .25 \mathrm{mg}$ sample was diluted in $25 \mathrm{ml}$ ethanol $96 \% .2 \mathrm{ml}$ of each concentration of standard solutions, as well as $1 \mathrm{ml}$ of each sample solution, were mixed with $3 \mathrm{~mL}$ ethanol $96 \%, 0.2 \mathrm{~mL}$ of aluminium chloride, $0.2 \mathrm{~mL}$ potassium acetate $1 \mathrm{M}$ and $5.6 \mathrm{~mL}$ of distilled water. The mixture was incubated at room temperature for 30 minutes. The absorbance was measured at $440 \mathrm{~nm}$ using Shimadzu 1800 UV-Vis spectrophotometer and the results expressed as weight of Quercetin Equivalent (QE) per gram of extract.

\section{Capsule preparation}

The EESP mixed with maydis starch to obtain a homogeneous mass. The mass was dried in oven at $55^{\circ} \mathrm{C}$ and then filled into 0 -sized capsule shells using a semi-automatic capsule filling device. The capsule contained 350mg ethanol extract of $S$. polyanthum leaves.

\section{Volunteer recruitment}

The volunteers were outpatients at Glugur Darat Primary Health Care, Medan, North Sumatera, Indonesia. Each volunteer was explained the study protocol and signed informed consent before acceptance. To participate in the study, the volunteer must fulfill the inclusion criteria, i.e diabetes mellitus type 2, consumed metformin during the study, no gastritis history, not in terminal illness, liver function (Serum Glutamic-Oxaloacetic Transferase (SGOT) and Serum GlutamicPyruvic Transferase (SGPT)) and kidney function (Ureum (Ur) and Creatinin $(\mathrm{Cr})$ ) not more than 2 times normal range. Any adverse effect or subjective symptoms that could not be tolerated by the subject was excluded from the study.

\section{Design}

The minimum sample size required in this study was calculated using the $\mathrm{G}$ power software..$^{22}$ A total of 12 volunteers was randomly given capsule contained EESP or placebo (Pl) (amylum) once daily along with metformin $500 \mathrm{mg}$ twice daily. Complete blood tests, liver (SGOT and SGPT) and kidney ( $\mathrm{Ur}$ and $\mathrm{Cr}$ ) function were carried out at the beginning and after 14 days of taking the capsules. During the administration any complaints experienced were recorded.

\section{Data analysis}

Data were analyzed using IBM SPSS Statistics 22 software. Results were presented as mean \pm standard deviation. Statistical significance was assessed with Mann-Whitney U or Independent T-Test; Wilcoxon Signed Ranks Test or Dependent T-Test.

\section{RESULTS}

\section{Total phenolics and total flavonoids}

Table 1 showed that EESP of this study contained phenol $161.64 \mathrm{mg} / \mathrm{g}$ in GAE and flavonoid $45.75 \mathrm{mg} / \mathrm{g}$ in QE.

\section{Volunteer observation}

During the observation, voluntary vital signs as recorded in normal range (data were not shown). Feeling sleepy, itchy, increased appetite, polyuria and numb were submitted by the Pl-group.

\section{Table 1: Total phenolics and total flavonoids.}

\begin{tabular}{|ccc|}
\hline EESP & $\begin{array}{c}\text { Total phenolics } \\
(\mathrm{mg} / \mathrm{g}) \text { in GAE }\end{array}$ & $\begin{array}{c}\text { Total flavonoids } \\
(\mathrm{mg} / \mathrm{g}) \text { in QE }\end{array}$ \\
\hline
\end{tabular}

(GAE: Gallic Acid Equivalent; QE: Quercetin Equivalent)

Table 2: Hb, liver and kidney function of the volunteers.

\begin{tabular}{|c|c|c|c|}
\hline \multirow[t]{2}{*}{ Group } & \multicolumn{2}{|c|}{$\begin{array}{c}\mathrm{Hb} \text { (Male: } 14.00-17.00) \\
\text { (Female:12.00-16.00) g/dl Mean } \pm \text { SD }\end{array}$} & \multirow[t]{2}{*}{$p^{b}$} \\
\hline & Day 0 & Day 14 & \\
\hline EESP & $12.60 \pm 1.27$ & $12.52 \pm 1.23$ & 0.52 \\
\hline $\mathrm{Pl}$ & $12.88 \pm 1.57$ & $12.76 \pm 1.36$ & 0.68 \\
\hline$p^{a}$ & 0.93 & 0.48 & \\
\hline
\end{tabular}

\begin{tabular}{|cccc}
\hline \multirow{2}{*}{ Group } & \multicolumn{2}{c}{$\begin{array}{c}\text { SGOT (5-35) U/L } \\
\text { Mean } \pm \text { SD }\end{array}$} & $p^{\mathrm{b}}$ \\
\cline { 2 - 4 } & Day 0 & Day 14 & \\
\hline EESP & $20.83 \pm 9.51$ & $24.16 \pm 13.57$ & 0.27 \\
Pl & $16.00 \pm 6.32$ & $19.83 \pm 13.45$ & 0.22 \\
$p^{a}$ & 0.39 & 0.31 & \\
\hline
\end{tabular}

\begin{tabular}{cccc} 
Group & \multicolumn{2}{c}{$\begin{array}{c}\text { SGPT (5-35) U/L } \\
\text { Mean } \pm \text { SD }\end{array}$} & $p^{\mathrm{b}}$ \\
\cline { 2 - 4 } & Day 0 & Day 14 & \\
\hline EESP & $25.66 \pm 18.25$ & $27.50 \pm 20.52$ & 0.34 \\
Pl & $17.83 \pm 8.61$ & $20.66 \pm 13.61$ & 0.27 \\
$p^{a}$ & 0.69 & 0.93 & \\
\hline
\end{tabular}

\begin{tabular}{|c|c|c|c|}
\hline \multirow[t]{2}{*}{ Group } & \multicolumn{2}{|c|}{$\begin{array}{c}\text { Ureum }(<50) \mathrm{mg} / \mathrm{dl}) \\
\text { Mean } \pm S D\end{array}$} & \multirow[t]{2}{*}{$p^{d}$} \\
\hline & Day 0 & Day 14 & \\
\hline EESP & $21.57 \pm 7.04$ & $23.12 \pm 13.27$ & 0.91 \\
\hline $\mathrm{Pl}$ & $26.33 \pm 5.87$ & $21.62 \pm 6.34$ & 0.12 \\
\hline$p^{c}$ & 0.67 & 0.31 & \\
\hline \multirow[t]{2}{*}{ Group } & \multicolumn{2}{|c|}{$\begin{array}{c}\text { Creatinin (0.6-1.3) } \mathrm{mg} / \mathrm{dl} \\
\text { Mean } \pm S D\end{array}$} & $p^{\mathrm{b}}$ \\
\hline & Day 0 & Day 14 & \\
\hline EESP & $0.65 \pm 0.10$ & $0.71 \pm 0.23$ & 0.17 \\
\hline $\mathrm{Pl}$ & $1.01 \pm 0.40$ & $1.03 \pm 0.40$ & 0.83 \\
\hline$p^{a}$ & 0.09 & 0.24 & \\
\hline
\end{tabular}

a:Mann-Whitney U Test; b:Wilcoxon Signed Ranks Test; c: Independent T-Test; d: Dependent T-Test

Table 3: Effect of EESP on MDA level.

\begin{tabular}{cccc}
\multirow{2}{*}{ Group } & \multicolumn{2}{c}{$\begin{array}{c}\text { MDA }(\mathrm{ng} / \mathrm{ml}) \\
\text { Mean } \pm \text { SD }\end{array}$} & $p^{\mathrm{b}}$ \\
\cline { 2 - 4 } & Day 0 & Day 15 & \\
\hline EESP & $1381.55 \pm 977.79$ & $1041.63 \pm 615.66$ & 0.22 \\
Pl & $1418.38 \pm 503.24$ & $1177.74 \pm 589.39$ & 0.34 \\
$p^{a}$ & & 0.05 & \\
\hline
\end{tabular}

a:Mann-Whitney U Test; b:Wilcoxon Signed Ranks Test 


\section{Effect of EESP on hemoglobin, liver and kidney function}

As shown in Table 2, the level of Hb, SGOT, SGPT, ureum and creatinin were in normal level. Statically, no significant different between day 0 and day 14 of the treatment.

\section{Effect of EESP on MDA level}

Table 3 showed the MDA level before and after 14 days intervention. The results showed that MDA reduction in the EESP-treated group was higher than Pl group. In EESP-, MDA decreased to $1041.63 \pm$ $615.66 \mathrm{ng} / \mathrm{ml}$ from $1381.55 \pm 977.79 \mathrm{ng} / \mathrm{ml}(24 \%)$, while in Pl-treated group from $1418.38 \pm 503.24 \mathrm{ng} / \mathrm{ml}$ to $1177.74 \pm 589.39 \mathrm{ng} / \mathrm{dl}(16 \%)$. However, statistically, there was no significant different between both of intervention $(\mathrm{p}>0.05)$.

\section{DISCUSSION}

Diabetes is strongly co-associated with oxidative stress induction. The use of antioxidants in both the treatment and prevention of diabetes was scrutinized in several studies. Recent studies reported contrasting findings regarding the benefits of antioxidant therapeutics in the management of diabetes. ${ }^{23}$

Syzygium polyanthum (Wight) Walp. or bay leaf commonly used as food flavoring in Indonesia. For herbal purpose, safety data in preclinical study reported that ethanol extract of $S$. polyanthum $1 \mathrm{~g} / \mathrm{kg}$ for 90 days not toxic on the hematology, creatinine and SGPT. ${ }^{24}$ In this study, safety report on liver (SGOT and SGPT level), renal function (Ur and Cr), and hemoglobin level showed that those parameters were in normal range. There were no significant changes on those profiles during observation.

The phytochemicals are responsible for the therapeutic activities of the plants including phenols and flavonoids. ${ }^{25-27}$ These compounds have been reported play a role to the antioxidant activity of plants. ${ }^{25}$ The present study showed that EESP contained phenolics (161.64 mgGAE/g extract) and flavonoids (45.57 mgQE/g extract). This results support the previous preclinical studies that reported the antioxidant properties of this plant. . $6,17,28,29^{-1}$

Evidences suggest that hyperglycemia plays a role in generation of reactive oxygen species (ROS). These ROS ultimately increase oxidative stress in a variety of tissues. ${ }^{15}$ One indicator of oxidative stress is malondialdehyde (MDA).$^{30} \mathrm{MDA}$ is a product that results from the degradation of polyunsaturated fatty acids in cell membranes. Reported levels of this product are higher found in diabetic patients. ${ }^{31}$ This condition may trigger an inflammatory process associated with blood vessel abnormalities in type $2 \mathrm{DM}$. The agents which can delay or prevent oxidative stress are called as antioxidants. ${ }^{32}$ Imbalance between oxidants and antioxidants can cause oxidative stress in pancreatic beta cells, subsequently involved in the pathophysiology of DM and its complications. ${ }^{33,34}$ MDA level was measured in the present study to evaluate the potency of $S$. polyanthum extract as an antioxidant agent in diabetic patients. In this study, administration of capsule containing EESP decreased MDA level greater than placebo for 14 days observation. High serum levels of MDA correlates with hyperglycemia because of self-oxidation of glucose and could generate free radicals. ${ }^{5}$ S. polyanthum leaves could inhibit a a-glucosidase enzyme which yields an effect similar to acarbose. The flavonoid compounds of the extract could help regenerate the dysfunctional pancreatic $\beta$-cell which could improve glucose control by optimizing insulin production. ${ }^{35}$ Its antioxidant activities mainly due to its flavonoids and phenols content that has strong antioxidant properties. ${ }^{11}$ However, the limitation of this study needs to be further investigated with wider range of volunteer and longer time of use. Along with this study, the treatment of $350 \mathrm{mg}$ of EESP was effective to lower fasting blood glucose level in patients with type 2 diabetes mellitus within 14 days observation. Fasting blood glucose level of EESP decreased from $186.25 \pm 58.57$ to $169.79 \pm 47.31$ (8.85\%; BGL difference $16.5 \mathrm{mg} / \mathrm{dl}){ }^{36}$

\section{CONCLUSION}

The reduction of MDA level after $S$. polyanthum ethanol extract leaf at dose of $350 \mathrm{mg}$ for 14 days administration showed its potency as antioxidant in type 2 diabetes mellitus patients.

\section{ACKNOWLEDGEMENT}

This research was funded by Ministry of Research and Technology and Higher Education Republic of Indonesia, Research and Community Service, University of Sumatera Utara, grant number: DRPM 2019 No.24/UN5.2.3.1/PPM/KP-DRPM/2019). Special thanks to dr. Sri Wirya Ningsih, Ayang Ludita, Amd., Apt. Lolyta Fitri Mustanti, S.Farm., Apt. Hayatun Nufus, S.Farm and Kholidah Putri Warni Dasopang, Amd. for technical support during data collection and manuscript preparation.

\section{CONFLICTS OF INTEREST}

The authors declare no conflicts of interest.

\section{REFERENCES}

1. World Health Organization. Diagnosis and Management of Type 2 Diabetes (HEARTS-D). Geneva: World Health Organization. 2020;9.

2. American Diabetes Association. Standards of Medical Care in Diabetes 2020. Diabetes Care. 2020;43(1):S1-S2.

3. Aliahmat NS, Noor MRM, Yusuf WJW, Makpol S, Ngah WZW, Yusof YAM. Antioxidant Enzyme Activity and Malondialdehyde Levels Can Be Modulated By Piper betle, Tocotrienol Rich Fraction And Chlorella vulgaris In Aging C57BL/6 Mice. CLINICS. 2012;67(12):1447-1454.

4. Son SM. Reactive Oxygen and Nitrogen Species in Pathogenesis of Vascular Complications of Diabetes. Diabetes \& Metabolism Journal. 2012;36:190-198.

5. Singh SR, Hijam D, Dubey A, Devi NO, Jamir S, Longkumer C. Study of Oxidative Stress Status in Type 2 Diabetic Patients. International Journal of Contemporary Medical Research. 2015;2(1):20-26.

6. Hernani. Pengembangan Biofarmaka sebagai Obat Herbal untuk Kesehatan. Buletin Teknologi Pascapanen Pertanian. 2011;7(1):21-29.

7. Ekor M. The growing use of herbal medicines: Issues Relating to Adverse Reactions And Challenges In Monitoring Safety. Frontiers in pharmacology. 2014;4(177):177.

8. Yusoff NA, Lim V, Al-Hindi B. Nypa fruticans Wurmb. Vinegar's Aqueous Extract Stimulates Insulin Secretion and Exerts Hepatoprotective Effect on STZ-Induced Diabetic Rats. Nutrients. 2017:9(9):925.

9. Widyawati T, Purnawan WW, Atangwho IJ, Yusoff NA, Ahmad M Asmawi MZ. Anti-diabetic Activity of Syzygium polyanthum (Wight) Leaf Extract, The Most Commonly Used Herb Among Diabetic Patients in Medan, North Sumatera, Indonesia. International Journal of Pharmaceutical Sciences and Research. 2015;6(4):1698.

10. Sutrisna E, Nuswantoro Y, Said RF. Hypolipidemic of ethanolic extract of Salam bark (Syzygium polyanthum (Wight) Walp.) from Indonesia (Preclinical study). Drug Invention Today. 2018;10:55-58.

11. Widyawati T, Yusoff NA, Asmawi M, Ahmad M. Antihyperglycemic Effect of Methanol Extract of Syzygium polyanthum (Wight.) Leaf in Streptozotocin-induced Diabetic Rats. Nutrients. 2015;7(9):7764-7780.

12. Tinneke LSV, Nova TP. Larvicidal Activity of Syzygium polyanthum W. Leaf Extract Against Aedes aegypti L Larvae. Progress in Health Sciences. 2015;5(1):102-106.

13. Zulcafli AS, Lim C, Ling AP, Chye S, Koh R. Antidiabetic Potential of Syzygium sp.: An Overview. Yale Journal of Biology and Medicine. 2020;93(2):307-325. 
14. Prahastuti S, Tjahjani S, Hartini E. The Effect of Bay Leaf Infusion (Syzygium polyanthum (Wight) Walp) to Decrease Blood Total Cholesterol Level in Dyslipidemia Model Wistar Rats. Jurnal Medika Planta. 2013;1(4).

15. Widharna RM, Tamayanti WD, Hendriati L, Hamid IS, Widjajakusuma EC. Antidiabetic Effect of The Aqueous Extract Mixture of Andrographis paniculata and Syzygium polyanthum Leaf. European Journal of Medicinal Plants. 2015;6(2):82

16. Widyawati T, Roslan NA, Yusoff NA, Asmawi MZ, Ahmad M. The Evaluation of Antioxidant and Free Radical Scavenging Activities of Eugenia polyantha leaves extracts. International Journal of ChemTech Research. 2016;465-471.

17. Hidayati MD, Ersam T, Shimizu K, Fatmawati S.. Antioxidant Activity of Syzygium polyanthum Extracts. Indonesian Journal of Chemistry. 2017;17(1):49-53.

18. Wahjuni S, Wita IW. Hypoglycemic and Antioxidant Effects of Syzygium polyanthum Leaves Extract on Alloxan Induced Hyperglycemic Wistar Rats. Bali Medical Journal. 2017;3(3):113-16.

19. Hamad A, Mahardika MGP, Yuliani I, Hartanti D. Chemical Constituents and Antimicrobial Activities of Essential Oils of Syzygium polyanthum and Syzygium aromaticum. Rasayan Journal of Chemistry. 2017;10(2):564-9.

20. Rahim ENAA, Ismail A, Omar MN, Rahmat UN, Ahmad WANW. GC-MS Analysis of Phytochemical Compounds in Syzygium polyanthum Leaves Extracted Using Ultrasound-Assisted Method. Pharmacognosy Journal. 2018;10(1).

21. Sumantri IB, Wahyuni HS, Mustanti LF. Total Phenolic, Total Flavonoid and Phytochemical Screening by FTIR Spectroscopic of Standardized Extract of Mikania micrantha Leaf. Pharmacognosy Journal. 2020;12(6):1395-1401.

22. Singa FA, Hasibuan $R$, Risfandi $M$, Marpaung RD, Jumadin IP, Sinaga R. Pengaruh Pemberian Jus Bit (Beta vulgaris L) Selama Latihan terhadap Kadar malondialdehide dan status antioksidan atlet. Sains Olahraga : Jurnal IImiah IImu Keolahragaan. 2019;3 (2): 119-130

23. Yusoff NA, Mun $Y$, Hooi-Kheng $B$, Khairul AR, Widyawati $T$, Roziahanim M, Mariam A, Mohamad A. Antidiabetic and antioxidant activities of Nypa fruticans Wurmb. vinegar sample from Malaysia. Asian Pacific journal of tropical medicine. 2015;8: 595-605.

24. Sumiwi SA, Zuhrotun A, Hendriani R, Rizal M, Levita J, Megantara S. Subchronic Toxicity of Ethanol Extract of Syzygium polyanthum (Wight) Walp. leaves on Wistar rat. The Indonesian Biomedical Journal. 2019;11(1):30.
25. Ismail A, Ramli NS, Mohamed M, Ahmad WANW. Acute and SubAcute Antihypertensive Effects of Syzygium polyanthum Leaf Extracts with Determination of Gallic Acid using HPLC Analysis. Pharmacogn J. 2018;10(4):663-671.

26. Widyawati T, Pase MA, Daulay M, Sumantri IB. Standardization and Phytochemoical Screening of Syzygium polyanthum Wight Leaf and Myrmecodia pendans Simplicia. ICOSTEERR 2018. 2018;114-116.

27. Tungmunnithum D, Thongboonyou A, Pholboon A, Yangsabai $A$ Flavonoids and Other Phenolic Compounds from Medicinal Plants for Pharmaceutical and Medical Aspects: An Overview. Medicines (Basel). 2018;5(3):93.

28. Firdaus AF. Pengaruh Ekstrak Daun Salam (Syzygium polyanthum Wight) sebagai Antioksidan terhadap Penurunan Kadar Malondialdehid (MDA) Tikus Putih (Rattus norvegicus strain wistar) Jantan Model Aterosklerotik (Doctoral Dissertation, University of Muhammadiyah Malang). 2016

29. Har L, Intan SI. Antioxidant Activity, Total Phenolics and Total Flavonoids of Syzygium polyanthum (Wight) Walp leaves. International Journal of Medicinal and Aromatic Plants. 2012;2(2):219-228

30. Ayala A, Muñoz MF, Argüelles S. Lipid Peroxidation: Production, Metabolism, and Signaling Mechanisms of Malondialdehyde and 4-hydroxy-2-nonenal. Oxidative medicine and cellular longevity. 2014;21.

31. Rani AJ, Mythili SV. Study on Total Antioxidant Status in Relation to Oxidative Stress in Type 2 Diabetes Mellitus. Journal of clinical and diagnostic research: JCDR. 2014;8(2):108.

32. Mallick M, Bose A, Mukhi S. Comparative Evaluation of The Antioxidant Activity of Some Commonly Used Spices. International Journal of PharmTech Research. 2016;9(1):1-8.

33. Wang J, Wang H. Oxidative Stress in Pancreatic Beta Cell Regeneration. Oxid Med Cell Longev. 2017;193-261.

34. Elgaml SA, Hashish EA. Clinicopathological Studies of Thymus vulgaris Extract Against Cadmium Induced Hepatotoxicity in Albino rats. Global J Pharmacol. 2014;8: 501-09.

35. Jananie RK, Priya V, Vijayalakshmi K.. Determination of Bioactive Components of Cynodon dactylon by GC-MS analysis. N. Y. Sci. J. 2011;4:16-20.

36. Widyawati T, Pase MA, Daulay M, Sumantri IB. Effect of Bay Leaf Ethanol Extract on Blood Glucose Level in Patients With Type 2 Diabetes Mellitus. The 6th International Conference on Public Health Best Western Premier Hotel, Solo, Indonesia, October 2324. 2019;613-617. 


\section{GRAPHICAL ABSTRACT}

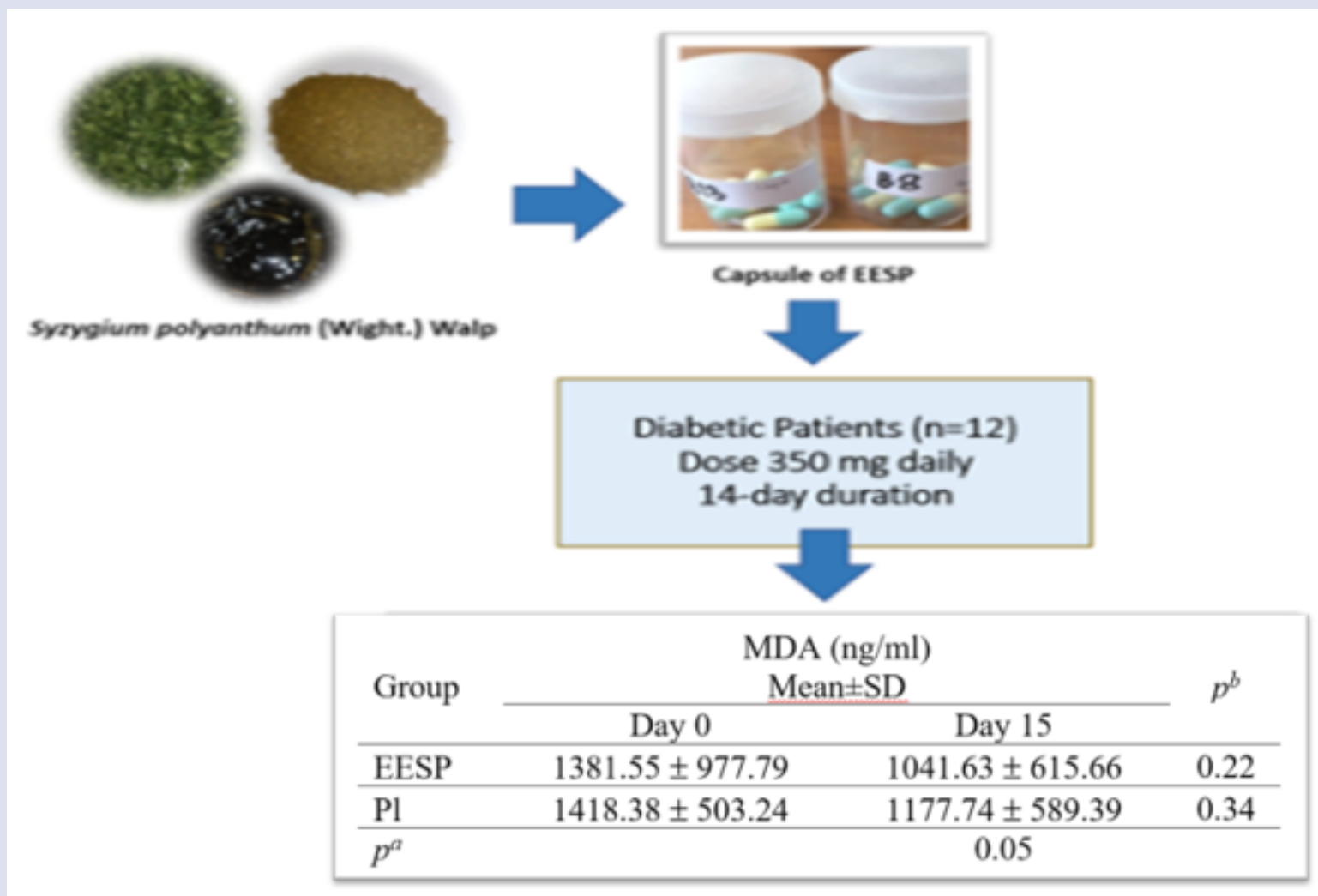

\section{ABOUT AUTHORS}

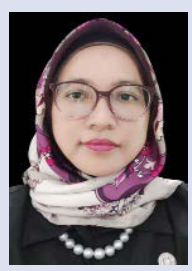

Tri Widyawati is a Lecturer at Medical Faculty, Pharmacology and Therapeutic Department, Universitas Sumatera Utara, Medan, Indonesia since 2003. Her PhD was graduated from Pharmaceutical Sciences University Sains Malaysia 2016. Her research interest is in pharmacological activity of medicinal plant especially on antidiabetic, antiinflammatory and immunomodulator properties.

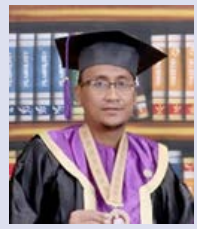

M Aron Pase, MD, a physician internist specializing in Endocrionology, Diabetes and Metabolisme Medicine at Haji Adam Malik Hospital JI Bunga Lau Medan. Lead of Indonesian Diabetes Association (PERSADIA) region of North Sumatera, with 2000 members at Sumatera. Certified in internal medicine, also a member of Indonesia Endocrine Society.

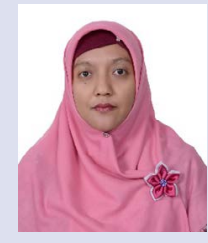

Milahayati Daulay is a lecturer at the Department of Physiology, Faculty of Medicine, Universitas Sumatera Utara, Medan, Indonesia. She completed undergraduate and general practitioner education in 2005 and master's education in biomedical science in 2011 at the Faculty of Medicine, Universitas Sumatera Utara. Currently, she is undergoing doctoral education at the same faculty in the field of Medical Sciences. She is active in various research activities together with other researchers in the fields of molecular biology, exercise physiology and pharmacology especially the use of herbal medicines in treating chronic noninfectious diseases such as diabetes mellitus.

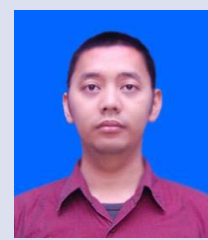

Imam Bagus Sumantri, is a lecturer and researcher at Department of Biology Pharmacy, Faculty of Pharmacy, Universitas Sumatera Utara. His current position is Head of Biology Pharmacy Laboratory, and his research fields focused on Biology Pharmacy such as Pharmacognosy, Traditional Medicine and Phytochemistry.

Cite this article: Widyawati T, Pase MA, Daulay M, Sumantri IB. Syzygium polyanthum (Wight.) Walp Ethanol Extract Decreased Malondialdehyde Level in Type 2 Diabetic Patients. Pharmacogn J. 2021;13(6)Supply: 1557-1561. 